\title{
PROFILE OF SAWMILLS IN THE UBÁ FURNITURE HUB IN THE STATE OF MINAS GERAIS
}

\author{
Vinicius Resende de Castro ${ }^{1}$ (D), Luciano Junqueira Costa ${ }^{2}$ (D) \& Wilton Ribeiro de Almeida ${ }^{3}$ \\ 1 - Professor PhD, UFV - campus Viçosa \\ 2 - Forest Engineer, Forest Science Doctorate student - UFV -Viçosa campus \\ 3 - Forest Engineer, UFV -Viçosa campus
}

\begin{abstract}
Keywords:
Eucalyptus

Lumber

Wood split

ABSTRACT

The objective of this work was to identify, diagnose and characterize the sawmills in four municipalities in the State of Minas Gerais (Divinésia, Senador Firmino, Brás Pires and Dores do Turvo) that provide lumber for the industries in the Furniture Hub in Ubá, State of Minas Gerais. A semi-structured questionnaire with open questions, answered in loco and accompanied by a responsible person (interviewer), with information on the identification of the potentialities and fragilities of the local lumber sector as well as to know the raw material (logs), the wood split processes, the internal management, the qualification of the employees, the machinery, products, market and prospects of the sector in these municipalities. It was found that Eucalyptus wood is the most used. The diameter of the logs is shown as the factor that affects the yield in $100 \%$ of the analyzed sawmills, where cracking and variability of the logs are the main difficulties of working with the raw material. The lumber sector in the analyzed municipalities needs a greater qualification, both managerial and technical, to improve the activity. In addition, it is necessary to better organize the companies related to the lumber sector through associations and support from local entities and greater exposure of the products to the local consumers.
\end{abstract}

Palavras-chave:

Desdobro da madeira

Eucalipto

Madeira serrada

\section{PERFIL DAS SERRARIAS DA REGIÃO DO POLO MOVELEIRO DE UBÁ (MG)}

\section{RESUMO}

O presente trabalho teve por objetivo a identificação, diagnóstico e caracterização das serrarias existentes em quatro municípios mineiros (Divinésia, Senador Firmino, Brás Pires e Dores do Turvo) que fornecem madeira serrada para as indústrias do Polo Moveleiro de Ubá (MG). Questionário semiestruturado com perguntas abertas, respondido in loco e acompanhado por responsável (entrevistador), com informações sobre a identificação das potencialidades e fragilidades do setor de madeira serrada na região, bem como para conhecer a matériaprima (toras), os processos de desdobro utilizados, o gerenciamento interno, a qualificação dos funcionários, o maquinário, os produtos, o mercado e as perspectivas do setor nesses municípios, foram utilizados. Verificou-se que a madeira de eucalipto é a mais utilizada. O diâmetro das toras aparece como fator que afeta o rendimento em $100 \%$ das serrarias analisadas, sendo o rachamento e variabilidade das toras as principais dificuldades de trabalho com a matéria-prima. $\mathrm{O}$ setor de madeira serrada nos municípios analisados necessita de uma maior qualificação, tanto gerencial quanto técnica, para aperfeiçoamento da atividade. Além disso, torna-se necessário uma maior organização das empresas ligadas ao setor de madeira serrada por meio de associações e apoio de entidades locais, e de uma maior divulgação dos produtos aos consumidores da região. 


\section{INTRODUCTION}

The use of wood from species of the genus Eucalyptus from planted forests may be an alternative to the demand for raw material for furniture production in Brazil (JUIZO et al., 2015). The Brazilian production of lumber in 2016 was 8.6 million $\mathrm{m}^{3}$, and used mainly in civil construction and furniture production (IBÁ, 2017).

The furniture hub of Ubá is located in the Forest Zone in the State of Minas Gerais and gathers nine municipalities in the region. The furniture activity started in the 1960s, with the manufacture of residential furniture in series aimed at the $\mathrm{C}$ and D social classes, considering the gross family income (FARAGE, 2013). Out of approximately 3,000 companies in the furniture sector in the State of Minas Gerais, three hundred are located in the furniture hub of Ubá. The region ranks the second place in number of industries and the first place in job creation, totaling approximately 19,000 people directly or indirectly linked to the furniture industry, covering the cities of Ubá, São Geraldo, Visconde do Rio Branco, Rodeiro, Tocantins, Piraúba, Guidoval and Rio Pomba, therefore corresponding to $45 \%$ of the furniture and mattress production in the State of Minas Gerais (SANTOS et al., 2019).

The furniture made in the furniture hub of Ubá consists of wood or wooden panels $(84.4 \%)$ and the rest are metal furniture $(7.6 \%)$ and mattresses $(8 \%)$. Although most of the furniture uses wood material (solid or panels), the companies use wood from local sawmills only to produce pieces (battens and boards) mainly for upholstery. The most used trees are of the species Eucalyptus sp., which are split into smaller pieces (slats) and sold to companies linked to the furniture hub of Ubá (DALÓLIO et al., 2017).

Because they could predict the use of lumber by the furniture industry of the Ubá hub, as well as the recent discussions on the restricted use of wood from native forests, the vast majority of rural producers have dedicated themselves to planting eucalyptus. In the region, the eucalyptus crop has been competing for several decades with agricultural crops such as coffee, corn, beans, cassava and fruit, as well as the extensive animal husbandry. As a result, the forestry vocation of the municipalities in question is evident, with countless eucalyptus plantations, since they have a privileged position in the furniture hub of Ubá (about 20 kilometers away).

However, the production of lumber requires splitting techniques that make the raw material and the existing machinery compatible to ensure good yield for sawn wood and especially good quality of the final product. The wood from most species of the genus Eucalyptus has intrinsic characteristics that hinder its processing in sawmills, where growth stresses, which result in top cracks and warping, are the main factors that affect the $\log$ splitting (LIMA; STAPE, 2017). There are several techniques that can be adopted both in preparation and in splitting to reduce the manifestations of growth stresses, thus minimizing losses during wood processing (PENG et al., 2015; ROCHA; TOMASELLI, 2002).

In this context, it arises the need to know the characteristics of sawmills in the micro-region that supply lumber for the furniture hub of Ubá (MG), in order to verify the potentialities and deficiencies that hinder their growth. The objective of this work was to carry out a diagnosis and characterization of sawmills in four municipalities in Minas Gerais (Divinésia, Senador Firmino, Brás Pires and Dores do Turvo), in order to provide subsidies for the regional development.

\section{MATERIAL AND METHODS}

To analyze the conditions of the sawmills, semi-structured questionnaires were applied to the sawmill owners in the municipalities of Divinésia, Senador Firmino, Brás Pires and Dores do Turvo (Figure 1).

A total of 13 sawmills existing in the cities analyzed were researched, some of which, even, in the condition of informality (not registered in the city). About 30 production variables, such as information on the identification of the potential and weaknesses of the lumber sector in the region, as well as to learn about the raw material $(\operatorname{logs})$, the unfolding processes used, the internal management, the qualification of the employees, the machinery, the products, the market and the perspectives of the sector in these municipalities were approached in order to offer the interviewee as many as possible 

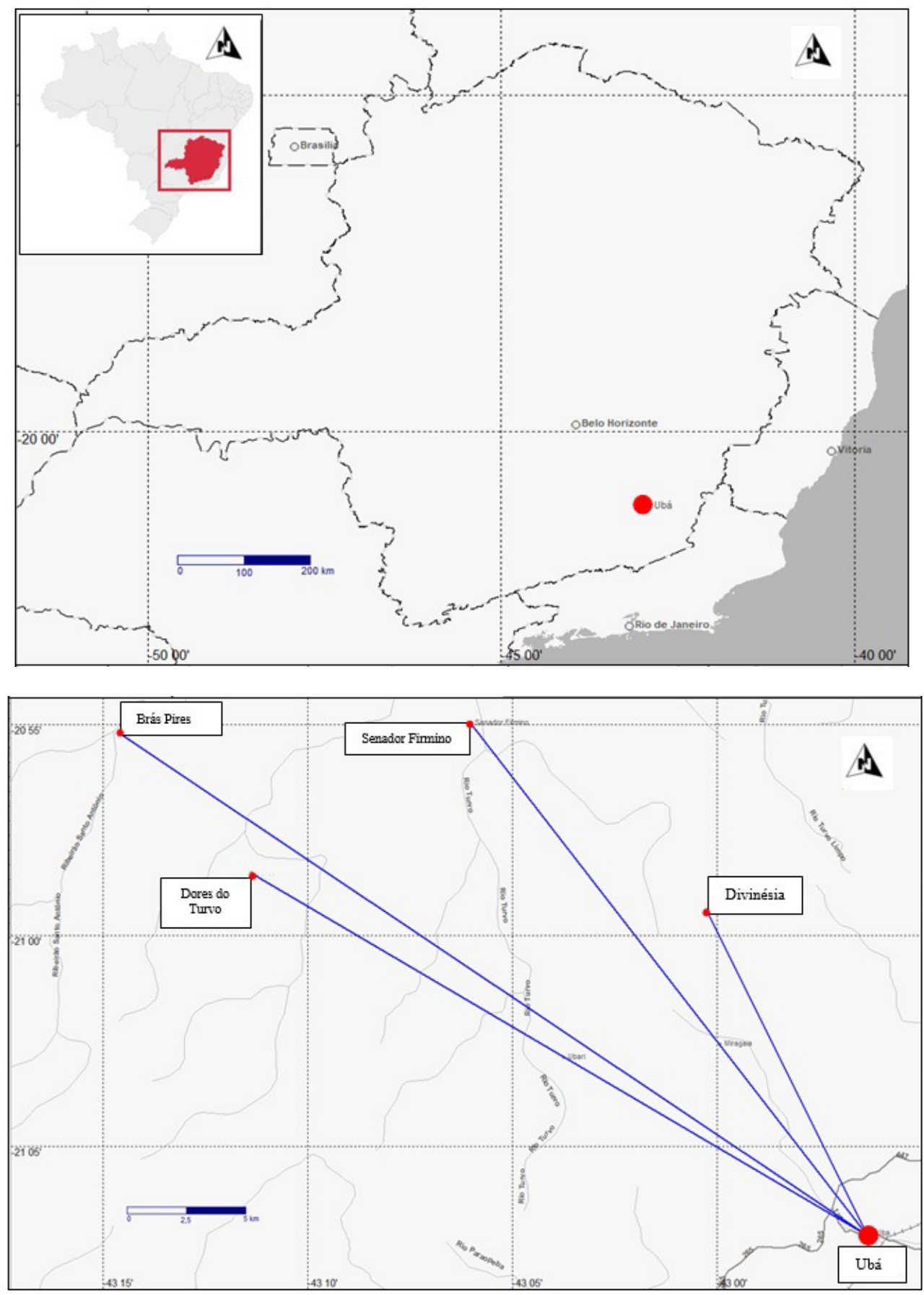

Figure 1. Localization of the municipalities in the study (Divinésia, Senador Firmino, Brás Pires and Dores do Turvo) regarding the Ubá furniture hub.

alternatives of answers.

Semi-structured questionnaires with open questions were answered by those in charge of the sawmill (previously scheduled), under the supervision of a responsible person (interviewer), collecting detailed information on the description of the enterprise, obtained through in loco observation, with emphasis on the following items: (i) profile of the entrepreneur; (ii) raw material; (iii) labor; (iv) technology used; (v) products; (vi) markets and (vii) layout.

The data regarding the answers of the semistructured questionnaire with open questions were organized and systematized by means of tabulation, using an electronic spreadsheet, and were presented in the form of graphs and tables. 


\section{RESULTS AND DISCUSSION}

Thirteen sawmills were found operating in the municipalities in the analysis, nine in Divinésia, two in Dores do Turvo, one in Brás Pires and one in Senador Firmino.

Regarding the raw materials (logs) used in all sawmills in this study, it was found that eucalyptus wood (trees of the different species of the genera Eucalyptus, Corymbia and Angophora) is the most used (92.3\%), and only one company uses Pinus $\operatorname{logs}(7.7 \%)$. The company that uses Pinus wood makes pallets and pieces for packaging, and suffers from the difficulty of finding raw materials in the region. For the opening of this single company, a Business Plan was not prepared, and therefore, the viability of the enterprise was not measured.

In relation to the origin of the raw material $(\operatorname{logs})$, in $76.9 \%$ of the cases, the wood is purchased from local suppliers (third-party forest) purchased both in the form of "standing timber" and in logs of different lengths and diameters; $23.1 \%$ of sawmills have their own plantations. In both cases, the forests are managed without specialized technical support and with rudimentary silvicultural treatments (without thinning and pruning) that result in a poorquality tree for the sawmill, therefore generating high losses and difficulties to enter new markets with higher quality requirements such as highgrade furniture

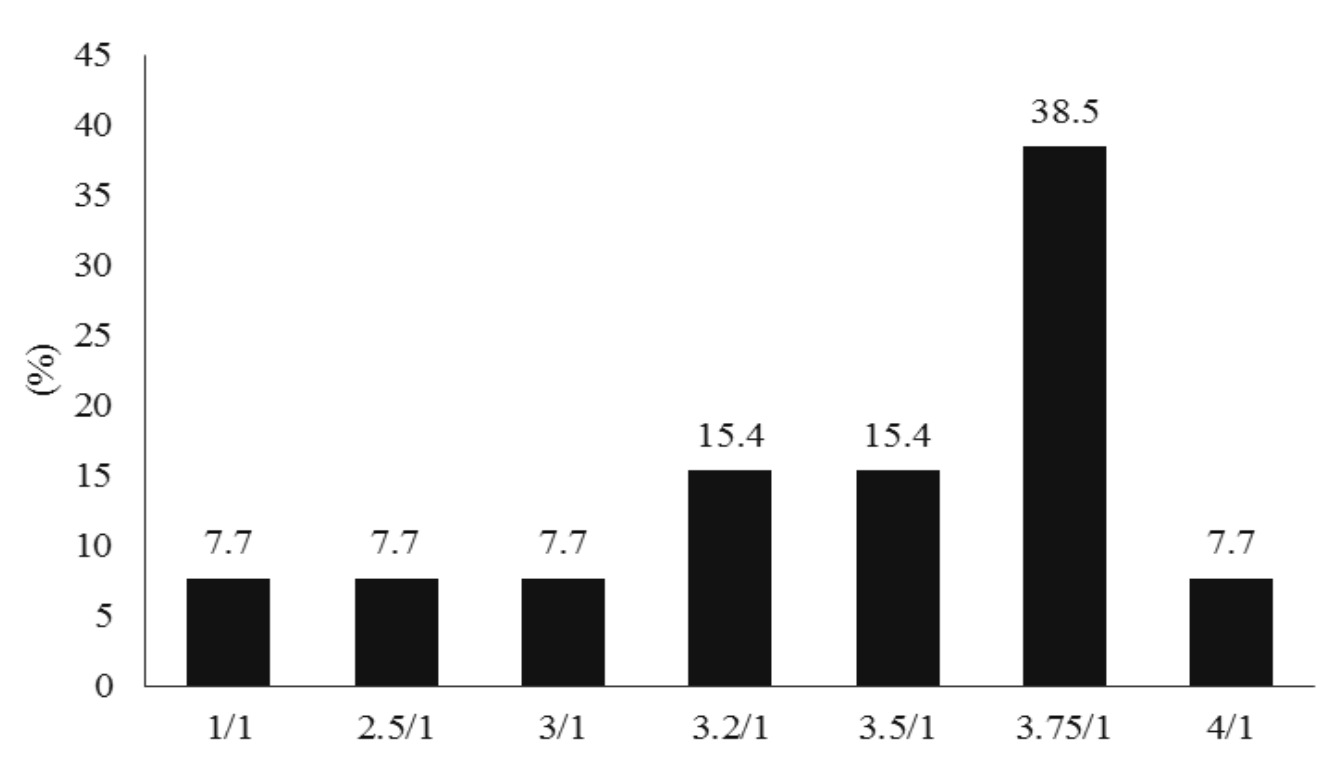

Figure 2. Percentage of the sawmill per yield rate $\left(\mathrm{m}^{3} \log / \mathrm{m}^{3}\right.$ lumber $)$.
In relation to lumber yield, it was found that the conversion of raw material (logs) into final product (Figure 2) is considered unsatisfactory as $38.5 \%$ of the analyzed sawmills use 3.75 cubic meters of timber in $\log$ to produce one cubic meter of sawn wood as slat (4 x $3 \times 100 \mathrm{~cm})$. Only one company obtains a productivity ratio of $1 / 1$, which refers exclusively to the production of wood chips, where the whole $\log$ is transformed into chips that are sold in a stere generating greater volume than that of the initial raw material. When transformed into the $1 \mathrm{~m}^{3}$ unit of sale, it equals 1.8 stere (st.).

In Brazil, the first planted forests used for the sawmill were implanted and managed without specific care for the production of sawn wood. According to data from IBÁ (2017), only 4\% of the entire area planted with forests in Brazil is conducted in an appropriate manner with the objective of destining production to solid wood products, that is, to sawmill.

According to Muller et al. (2018), the average expected yield for eucalyptus sawmills is 45 to $55 \%$, that is, from $(2.22 / 1)$ to $(1.81 / 1)$ in $\mathrm{m}^{3}$ of unsawn timber to $\mathrm{m}^{3}$ of sawn wood. Based on this author, it can be said that the earnings of the companies evaluated are below the expectations and changes need to be implemented to improve the raw material, the sawing machinery and the training of the workforce, in order to optimize the performance. 


\section{PROFILE OF SAWMILLS IN THE UBÁ FURNITURE HUB IN THE STATE OF MINAS GERAIS}

Several factors that affect the yield were listed, among them, the log diameter was answered by $(100 \%)$ of the interviewees, followed by $\log$ quality $(38.5 \%)$; tree species $(23.1 \%)$; cutting thickness (23.1\%); processing methods and number of alternative products (15.4\%) and operator's personal decisions (7.7\%). However, simple measures such as improvement courses, consultation with specialists and the search for support from entities such as IEF, Emater, Senar, Senai, the local Sebrae and Universities, have the potential to mitigate the effect of the factors that are presented. It is important to highlight that there are no professionals specialized in forests for sawmills in the supervision and management of the companies' productive sector, and the information obtained in the research is totally empirical, based on daily practical experience with the production.

In relation to the difficulties faced in the use of wood, the cracks found on the top of logs and the variability of the logs were shown by $(69.2 \%)$; inadequate diameter (53.8\%); warping (38.5\%); maintenance of stocks/delivery frequency $(30.8 \%)$; presence of nodes (23.1\%); lack of knowedlge of the best method to work with wood (15.4\%); resin bags (15.4\%); juvenile wood (7.7\%). Changes in the silvicultural tract (thinning and pruning), from planting to harvest, improvement of unfolding techniques, planning of the cutting diagram, proper sharpening of the saw blades and adequate machines which should be more modern and in good condition, in addition to sawing logs with maximum humidity and adequate drying of the sawn wood could significantly collaborate to mitigate the effects of the listed items.

Average gross yields obtained for $E$. dunnii and $E$. deanei between 48.34 and $61.35 \%$ after unfolding and between 45.10 and $56.70 \%$ after drying meet the values found for the genus in the literature, including those observed for species already recommended for the production of lumber in Brazil, such as E. grandis and E. saligna (MÜLLER et al., 2017). Different Eucalyptus clones, after the unfolding with an average yield of $44.49 \%$ for E. grandis and $48.29 \%$ for E. saligna were found by Anjos and Fontes (2017). On the other hand, Carvalho and Nahuz (2002), when studying E. grandis x E. urophylla, observed, after drying, the average yield of $39.71 \%$.

Figure 3 shows the wood consumption in the sawmill in the four analyzed municipalities.

The consumption of raw material, that is, wood in logs is an indicator of the size of the evaluated sawmills. It was possible to divide the data into two large groups, sawmills that process between 100 and $499 \mathrm{~m}^{3}$ of wood per month, where they are represented by $38.5 \%$ of the industries; and the group that processes between 500 and $999 \mathrm{~m}^{3}$

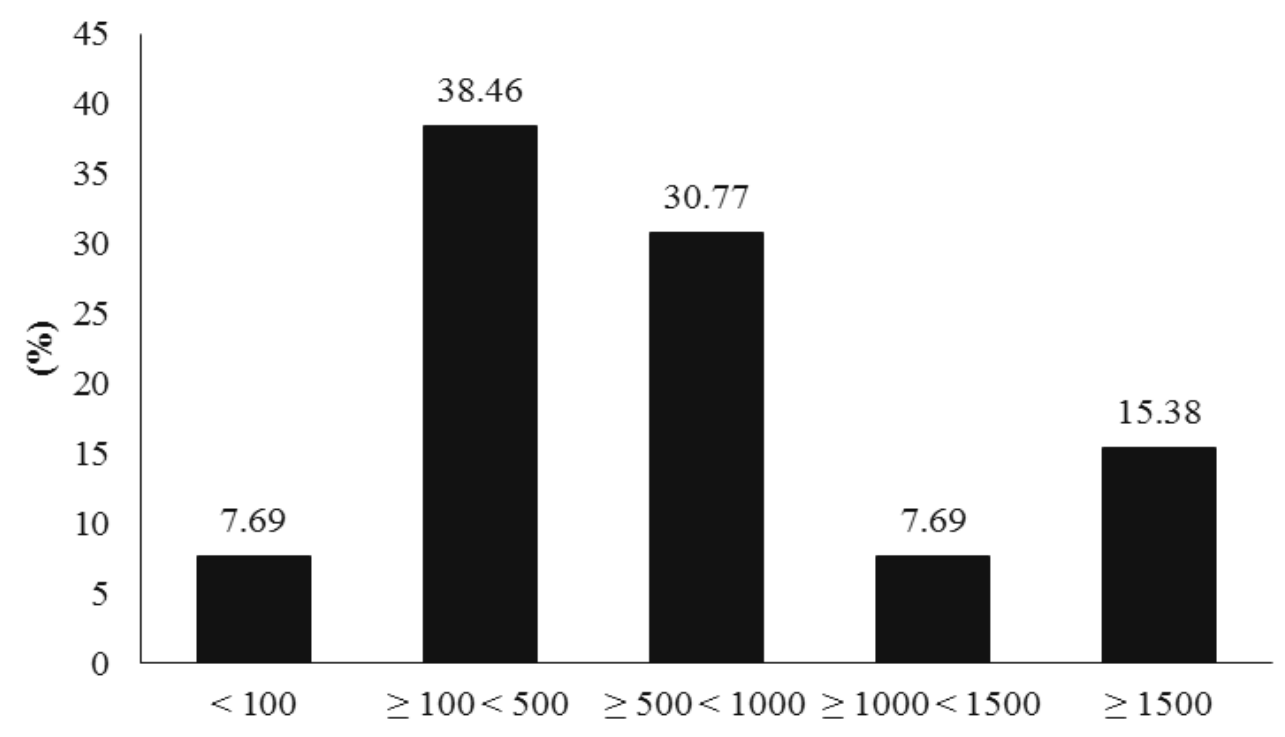

Figure 3. Consumption of raw material $\left(\mathrm{m}^{3}\right.$ of the wood in logs) by the sawmills. 
of wood per month, representing $30.8 \%$. Microsawmills that work with less than $100 \mathrm{~m}^{3}$ of raw material per month suffer from the low dilution of fixed costs, which reduces the profitability.

The machinery of main saws, single band saws and multiple circular saws or Multisaws are found in the evaluated sawmills. The circular saws, aligner or chisel and cross-cut were also found in the evaluated sawmills (Figure 4).

Table 1 shows the efficiency of the production factors used in the sawmill, where machines can be equivalent to the capital and number of employees to the labor factor. The relationships (consumption $\left(\mathrm{m}^{3}\right) /$ capital) and (consumption $\left(\mathrm{m}^{3}\right) /$ labor) indicate the productivity of these factors, respectively.

The sawmills can be classified by the volume of the timber processed in: small size up to 50 $\mathrm{m}^{3} /$ shift; medium size between 50 and $100 \mathrm{~m}^{3 /}$ shift and large size above $100 \mathrm{~m}^{3} / \mathrm{shift}$ (JUIZO et al. 2014). Thus, it can be seen that all the three analyzed sawmills are considered small. Small sawmills are more plastic (they are easier to adapt to market demands) and also efficient, potentially more successful than the large ones. However, the greater the application of knowledge in unfolding methods, adequate equipment and good quality raw material, the greater the yields (VITAL, 2008).

The diameter of the logs is one of the main factors that affect the lumber yield (JUIZO et al.,

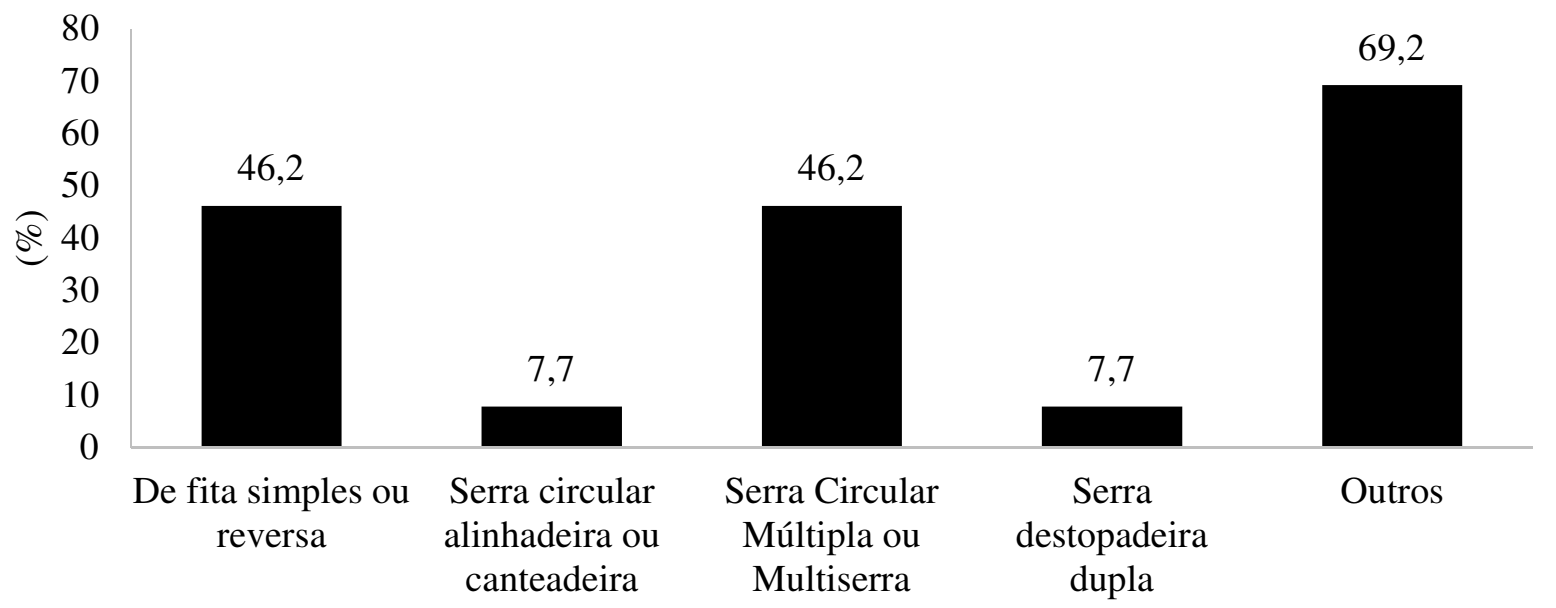

Figure 4. Percentage of the sawmills per type of machinery used for the unfolding.

Table 1. Relationship between production resources.

\begin{tabular}{|c|c|c|c|c|c|c|c|c|c|c|c|c|c|}
\hline \multirow{3}{*}{ Parameters } & \multicolumn{13}{|c|}{ Sawmills/municipalities } \\
\hline & $\mathrm{DV}^{1}$ & DV & DV & DV & DV & DV & DV & VD & DV & DT & DT & $\mathrm{BP}$ & SF \\
\hline & 1 & 2 & 3 & 4 & 5 & 6 & 7 & 8 & 9 & 10 & 11 & 12 & 13 \\
\hline $\begin{array}{l}\text { Wood consumption } \\
\left(\mathrm{m}^{3} / \text { month }\right)\end{array}$ & 1600 & 200 & 90 & 100 & 400 & 600 & 1700 & 400 & 550 & 1200 & 400 & 600 & 600 \\
\hline $\begin{array}{c}\text { Number of } \\
\text { machines }\end{array}$ & 7 & 3 & 1 & 1 & 3 & 3 & 3 & 1 & 2 & 2 & 2 & 4 & 1 \\
\hline $\begin{array}{c}\text { Consumption }\left(\mathrm{m}^{3}\right) / \\
\text { machine }\end{array}$ & 229 & 67 & 90 & 100 & 133 & 200 & 567 & 400 & 275 & 600 & 200 & 150 & 600 \\
\hline $\begin{array}{l}\text { Number of } \\
\text { employees }\end{array}$ & 18 & 0 & 4 & 4 & 22 & 14 & 18 & 0 & 8 & 8 & 4 & 12 & 20 \\
\hline $\begin{array}{c}\text { Consumption }\left(\mathrm{m}^{3}\right) / \\
\text { employee rate }\end{array}$ & 89.9 & - & 22.5 & 25 & 18.2 & 42.9 & 94.4 & - & 68.8 & 150 & 100 & 50 & 30 \\
\hline
\end{tabular}

${ }^{1}$ Legend: DV = Divinésia; DT = Dores do Turvo; $\mathrm{BP}=$ Brás Pires; $\mathrm{SF}=$ Senador Firmino. 
2015). In addition, according to the authors, the average yield in sawn wood in logs with a diameter within the range of 40 to 45 centimeters is about $45 \%$ while in logs with diameters ranging from 50 to 55 centimeters, the yield reaches $58 \%$. However, Del Menezzi and Nahuz (1998), when studying the unfolding of logs of Eucalyptus grandis, observed a reduction in the average yield with the increase in the average diameter of the logs, and suggested that besides the diameter, other factors such as the quality of the log (taper, presence of nodes, cracks, top cracks and tortuosity), the unfolding technique used and the equipment used in the cutting operations can also interfere in the lumber yield. Bonato Junior et al. (2017) found that the taper of the logs resulted in a reduction in the lumber yield, in addition to impairing log unfolding.

Wood from species of the genus Eucaylptus has some intrinsic characteristics such as high dimensional instability and the presence of inner growth stresses that hinder its processing and result in a reduction in the lumber yield (CUNHA et al., 2015). These characteristics are responsible for the emergence of defects, such as cracks, which cause considerable losses of raw material and in some situations may result in the unfeasibility of certain species. According to Blackwell and Walker (2006), the lumber yield is expressed as a percentage and obtained through the relationship between the volume of lumber and the volume of logs. In general, for eucalyptus, it varies between 40 and $65 \%$. Among the factors that influence the yield to be achieved, in addition to the characteristics inherent to the species, there are also the products to be obtained, machinery, available labor, quality and diameter of the logs to be processed (TSOUMIS, 1991). In this sense, the selection of logs through diametric classes and the establishment of cutting models for each of them, stand out as important strategies for optimizing yield and increasing productivity (MÜLLER et al., 2017).

Juizo et al. (2014) and Müller et al. (2018), concluded in their studies that the unfolding method affects the yield of eucalyptus lumber, and the appropriate choice of processing techniques can mitigate the effects of the growth stresses, avoiding cracks in the sawn wood.
The machinery used in the unfolding step can generate variations in the conversion factor of the raw material (logs) into lumber (FARAGE et al., 2013). Moreover, according to the author, the fewer the cutting processes to obtain the final product, the greater the yield, as it will reduce the production of waste, the demand for labor and the risk of accidents.

As a rule, the equipment used by the sawmills in the study is outdated in relation to those found on the market nowadays, in addition to not undergoing periodic preventive maintenance, and corrective maintenance to be carried out by the employees without specialized training. Only more complex defects have the attention of an experienced professional. Silva and Oliveira (2001) stress that the situation and maintenance of the machines and blades directly affect the performance of the sawmill. They also mention that regular sharpening must be done periodically to prevent changes in the quality of the cutting.

It was observed in the sawmills analyzed in this study the use of old and improvised machines. The personnel in charge for the sawmill were asked why they did not use newer and more modern machines, and it was found that the changing of machines involves several issues, especially the necessary input of capital and the low level of instruction of the operators. In general, industry consider outdated the equipment at 5 to 10 years of use (WALKER et al., 1993).

The following cases can be observed: the sawmill 10 has two machines which have a productivity of $600 \mathrm{~m}^{3} /$ machine, in contrast, sawmill 1 has seven machines and their productivity is only $229 \mathrm{~m}^{3} /$ machine. Sawmill 5 has twenty-two employees with productivity of $18 \mathrm{~m}^{3} /$ employee, while sawmill 11 has four employees with productivity $100 \mathrm{~m}^{3} /$ employee. Thus, idleness of certain factors of production is observed in some sawmills, which can raise the production costs without a fair return on production, which may worsen the financial health of these companies.

The production of lumber in the municipalities in this study is mostly destined to the furniture sector, in which $84.6 \%$ of sawmills operate in this market segment (Figure 5). 


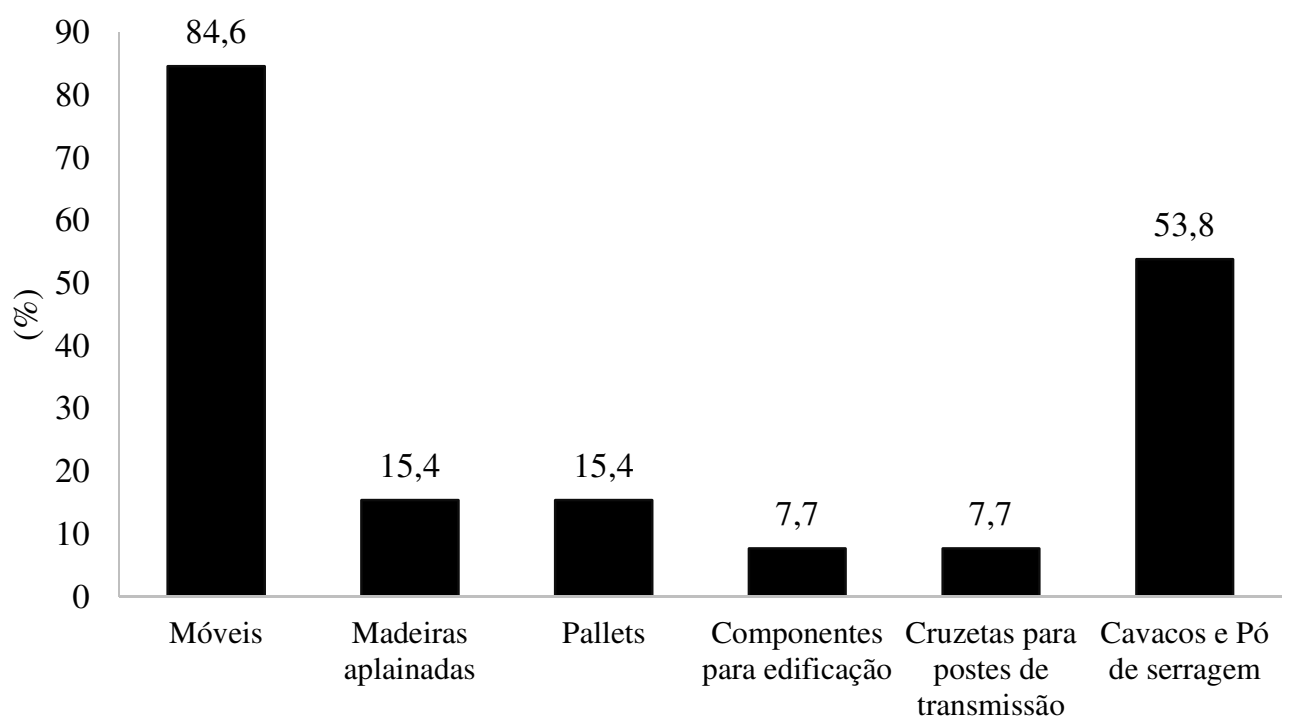

Figure 5. Percentages of the sawmills for their participation in a particular segment of the market.

To optimize the resource, $53.8 \%$ are inserted in the energy and agricultural markets with the sale of chips and sawdust, for burning in potteries and poultry farms. The sectors of planed wood and pallets are found in $15.4 \%$ and the building components and crosspieces for energy transmission poles in $7.7 \%$.

The Law of Diminishing Marginal Returns emphasizes that successive increases in a factor of production and the others are held constant, therefore contributing to an increase in production, but the rates are progressively smaller, that is, the increases in production occur at decreasing rates (ROMER; CHOW, 1996). Thus, it is possible to see that the deficiency in human management collaborates to prevent the expansion of the business.

Analysis of the performance the economic evaluation of a sawmill must be carried out in a complete manner, leading to the exhaustion of all factors relevant to the enterprise, as well as the technical and scientific basis that are already described in the literature. The efficiency of sawmills can be increased, primarily by hiring specialized professionals, responsible for managing the production process and making adjustments in the enterprise, such as optimizing the layout of the work area, planning and controlling production, carrying out periodic maintenance on equipment and training the employees (BATISTA et al., 2013).

It could be seen that entrepreneurs are willing to expand the number of products and segments in which they operate, however, the limitation of capital, labor and quality raw materials prevent them from moving forward. In this sense, it is necessary the intervention of financing entities that inject capital and technology transfer both in the production of raw material and in sawmills, also offering specialized technical support to break the chain that prevents the sector from advancing.

Based on the questionnaires, it is possible to observe that there is a lack of government support (municipal, state and federal) in the form of supporting policies, aligned with the excessive tax burden, being one of the recurring points in the complaints of entrepreneurs. The absence of special credit lines for the purchase of machinery and implements by public and private financial institutions is a limiting factor for the expansion of the business. This question leads to a disbelief in the sawn wood sector in the analyzed municipalities.

\section{CONCLUSION}

- Based on the results obtained in the study, it can be concluded that, as a rule, the sawmills analyzed in the Minas Gerais municipalities of Divinésia, Senador Firmino, Brás Pires and Dores do Turvo use as raw material, the eucalyptus wood purchased from local suppliers. In general, the supply of wood is abundant, but of a poor quality. 
- The 13 companies (sawmills) have some operational difficulties, especially regarding the quality of raw materials (logs) and quality of labor. These difficulties directly affect the yield and the volume of the wood sawn per month.

- Although the furniture hub in Ubá represents a great opportunity to sell the production, the variety of products is small, impairing its entering into more segments of the market.

- Idleness was found in the production factors, which affects the cost of the marginal product and indicates a poor management process. The companies have quite different sizes, both from the perspective of raw material consumption and from the number of employees.

- There is a need for a greater qualification, both managerial and technical, to improve lumber activities. In addition, a greater organization is required through associations and support from entities, such as the local SEBRAE, as well as the dissemination of products to local consumers. Thus, projects for the sector must consider the peculiarities of each enterprise.

\section{ACKNOWLEDGMENTS}

The authors thank CNPq, Fapemig and Capes for the financial support and also for the assistance given for the execution of this work.

\section{REFERENCES}

ANJOS, R.A.M.; FONTE, A.P.N. Rendimento de madeira serrada de espécies de Eucalyptus. Revista de Ciências Agro veterinárias, v.16, n.1, p.26-32, 2017.

BATISTA, D.C.; SILVA, J.G.M.; CORTELETTI, R.B. Desempenho de uma serraria com base na eficiência e na amostragem do trabalho. Floresta e Ambiente, v.20, n.3, p.271-280, 2013.

BLACKWELL, P.; WALKER, J.C.F. Sawmilling. In: WALKER, J.C.F. (ed.) Primary wood processing: principles and practice. Berlin: Springer, 2006.
BONATO JUNIOR, A.I.; ROCHA, M.P.; JUIZO, C.G.F.; KLITZKE, R.J. Efeito do sistema de desdobro e das classes diamétricas no rendimento em madeira serrada de Araucaria angustifólia. Floresta e Ambiente, v.24, n.1, p.1-8, 2017.

CARVALHO, M.A.; NAHUZ, M.A.R. Ensaios com madeira serrada de eucalipto jovem obtida de um plantio destinado à indústria de celulose. Revista Árvore, v.26, n.1, p.83-91, 2002.

CUNHA, A.B.; BRAND, M.A.; SIMÃO, R.L.; MARTINS, A.S.; ANJOS, R.A.M.; SURDI, P.G.; SCHIMALSKI, M. B. Determinação do rendimento de matéria-prima de Eucalyptus Benthamii Maiden \& Cambage por meio de diferentes métodos de desdobro. Revista Árvore, v.39, n.4, p.733-741, 2015.

DALÓLIO, F.S.; SILVA, J.N.; BAÊTA, F.C.; TINÔCO, I.F.F.; CARNEIRO, A.C.O. Cama de frango e resíduo moveleiro: alternativa energética para a zona da mata mineira. Revista Engenharia na Agricultura, v.25, n.3, p.261-271, 2017.

DEL MENEZZI, C.H.S.; NAHUZ, M.A.R. Comportamento de Eucalyptus grandis [Hill ex Maiden] no desdobro. Revista Árvore, v.22, n.4, p.563-571, 1998.

FARAGE, R.M.P. Avaliação do potencial de aproveitamento energético dos resíduos de madeira e derivados gerados em fábricas do polo moveleiro de Ubá - MG. Ciência Florestal, v.23, n.1, p.203212, 2013.

INDÚSTRIA BRASILEIRA DE ÁRVORES IBÁ. Anuário estatístico da IBÁ: ano base 2017. Brasília: IBÁ, 2016.

JUIZO, C.G.F.; ROCHA, M.P.; BILA, N.F.B. Avaliação do rendimento em madeira serrada de eucalipto para dois modelos de desdobro numa serraria portátil. Floresta e Ambiente, v.21, n.4, p.543-550, 2014.

JUIZO, C.G.F.; LOIOLA, P.L.; MARCHESAN, R.; JOSSÉFA, C.G.; CHAÓRA, I.J.; ROCHA, M.P.; 
KLITZKE, R.J. Influência da classe diamétrica no rendimento em madeira serrada de duas espécies nativas de Moçambique. Pesquisa Florestal Brasileira, v.35, n.83, p.293-298, 2015.

LIMA, I.L.; STAPE, J.L. Caracterização da madeira serrada em clones de Eucalyptus. Pesquisa Florestal Brasileira, v.37, n.89, p.55-62, 2017.

MÜLLER, B.V.; ROCHA, M.P.; KLITZKE, R. J.; DA SILVA, J.R.M.; CUNHA, A.B. Avaliação de viabilidade técnica da produção de madeira serrada de árvores de Eucalyptus benthamii de rotação reduzida. Ciência da Madeira, v.9, n.2, p.95-103, 2018.

MÜLLER, B.V.; ROCHA, M.P.; KLITZKE, R.J.; DA SILVA, J.R.M.; CUNHA, A.B. Produção de madeira serrada com cinco espécies de eucalipto resistentes à geada. Advances in Forestry Science, v.4, n.4, p.195-201, 2017.

PENG, Y.; ARNOLD, R.; WASHUSEN, R.; XIANG, D.; WU, G.; CHEN, S. Processing sawn wood from thinned, unpruned 17- year-old Eucalyptus dunnii in southern China. Australian Forestry, v.78, n.2, p.73-85, 2015.
ROCHA, M.P.; TOMASELLI, I. Efeito do modelo de desdobro na qualidade da madeira serrada de Eucalyptus grandis e Eucalyptus dunnii. Cerne, v.8, n.2, p.70-83, 2002.

ROMER, D.; CHOW, C. Advanced macroeconomic theory. New York: Mcgraw-hill, 1996.

SANTOS, V.J,; OLIVEIRA M.P.J. Indústria moveleira e dinâmica demográfica de Ubá, Minas Gerais. Sociedade \& Natureza, v.31, n.15, p.1-10, 2019.

SILVA, J.C.; OLIVEIRA, J.T.S. Diagnóstico do setor moveleiro no Brasil. Viçosa: Universidade Federal de Viçosa, 2001.

TSOUMIS, G. Science and technology of wood: structure, properties, utilization. New York: Chapman \& Hall; 1991.

VITAL, B.R. Planejamento e operações de serrarias. Viçosa: Universidade Federal de Viçosa. 2008.

WALKER, J.C.F. The drying of timber. In: Walker, J.C.F. Primary wood processing: principles and practice. London: Chapman \& Hall; 1993. 